\title{
Belajar Sumber Daya Alam Melalui Media Komik Digital
}

\section{Komang Ayu Megantari ${ }^{*}$, I Gede Margunayasa2, I Gusti Ayu Tri Agustiana3}

${ }^{123}$ Program Studi Guru Sekolah Dasar, Universitas Pendidikan Ganesha, Singaraja, Indonesia

\section{A R T I C LE IN F O}

\section{Article history:}

Received 1 Januari 2021

Received in revised form 30 Januari 2021

Accepted 1 Maret 2021 Available online 8 April 2021

\section{Kata Kunci:}

komik digital, sumber daya alam

Keywords: digital comic, natural resources

\begin{abstract}
A B S T R A K
Ketersediaan media pembelajaran inovatif di sekolah masih terbatas khususnya pada muatan IImu Pengetahuan Sosial topik sumber daya alam siswa kelas IV SD. Penelitian pengembangan ini bertujuan untuk mengembangkan media komik digital pada topik sumber daya alam yang teruji validitasnya. Model pengembangan dalam penelitian ini yaitu ADDIE yang terdiri dari beberapa tahapan yaitu analyze (analisis), design (perancangan), development (pengembangan), implementation (implementasi), dan evaluation (evaluasi). Subjek dalam penelitian ini berupa produk media komik digital topik sumber daya alam, sedangkan objek dalam penelitian ini yaitu validitas media komik digital pada topik sumber daya alam siswa kelas IV SD. Metode dan instrumen pengumpulan data penelitian ini menggunakan rating scale berupa lembar penilaian yang diberikan kepada 2 orang ahli materi, 2 orang ahli media, 2 orang praktisi dan 5 orang siswa kelas IV SD untuk mengetahui validitas media komik digital. Hasil analisis data yang diperoleh kemudian dianalisis untuk mengetahui validitas media komik digital menggunakan rumus indeks validitas Aiken dan rumus mean. Hasil indeks
\end{abstract} validitas Aiken memperoleh hasil indeks terendah dari ahli materi sebesar $0.88,0.63$ dari ahli media dan indeks tertinggi 1. Respon guru memperoleh skor sebesar 4.62 dan respon siswa sebesar 4.95 dengan predikat sangat baik. Media komik digital valid secara isi dan layak digunakan sebagai sumber belajar.

\begin{abstract}
A B S T R A C T
The availability of innovative learning media in schools is still limited, especially on Social Sciences subject on the topic of natural resources for fourth grade elementary school students. This research development aims to develop digital comic media on the topic of natural resources that its validity has been tested. The development model in this research is ADDIE which consists of several stages, that are analyze, design, development, implementation and evaluation. The subject in this research was digital comic media product on the topic of natural resources, meanwhile the object in this study was the validity of digital comic media on the topic of natural resources for fourth grade elementary school students. The method and instrument of data collection in this research used a rating scale in the form of an assessment sheet given to 2 material experts, 2 media experts, 2 practitioners and 5 grade IV SD students to find out the validity of digital comic media. The results of data analysis that were obtained, then they were analyzed to determine the validity of digital comic media using the Aiken validity index formula and the Mean formula. The results of the Aiken validity index obtained the lowest index results from material experts of 0.88, 0.63 from media experts and the highest index was 1. The teacher's response got a score of 4.62 and the student response was 4.95 with a very good predicate. Digital comic media is valid and suitable as a learning resource.
\end{abstract}

\section{Pendahuluan}

Media adalah bagian yang tidak dapat dipisahkan dari proses belajar mengajar untuk mencapai tujuan pembelajaran (Firmadani, 2020). Media juga merupakan salah satu komponen pembelajaran yang dapat menentukan keberhasilan suatu pembelajaran (Kharisma, 2020). Dimana dalam proses pembelajaran guru dituntut untuk mengurangi penggunaan metode ceramah dan diganti dengan penggunaan media pembelajaran. Dengan penggunaan media mampu membantu menyampaikan materi pembelajaran agar lebih bermakna dan menjadi lebih jelas sehingga tujuan pembelajaran dapat tercapai dengan efisien dan efektif (Dwijayani, 2019; Pradiatiningtyas \& Suparwanto, 2017). Media 
pembelajaran merupakan salah satu perantara yang digunakan dalam proses pembelajaran untuk mempermudah siswa dalam memahami suatu materi pembelajaran (Larasati et al., 2020). Media memiliki fungsi sebagai alat untuk membantu mempermudah guru dalam menyampaikan materi pembelajaran secara lebih konkret yang turut mempengaruhi motivasi dan minat siswa dalam pembelajaran (Muammar \& Suhartina, 2018).

Kenyataannya, dalam proses pembelajaran banyak guru yang belum menggunakan media audio visual saat pembelajaran yang disebabkan karena guru masih kurang terampil dalam menggunakan media tersebut. Akhirnya dalam proses pembelajaran di kelas guru lebih dominan menjelaskan materi tanpa adanya media pembelajaran (Abdullah, 2017; Lestari et al., 2018). Permasalahan lain seperti guru masih kesulitan dalam memilih media pembelajaran yang sesuai dengan kondisi pembelajarannya (Anugraheni, 2017) dan kompetensi teknologi guru masih kurang untuk mengembangkan media berbasis komputer secara mandiri (Sinsuw \& Sambul, 2017), penggunaan media pada pembelajaran IPS masih kurang maksimal. Begitupun ketersediaan media pembelajaran IPS di sekolah belum banyak dikembangkan hanya menggunakan media visual yang kurang interaktif seperti gambar dan globe (Setiawati et al., 2019).

Hal tersebut diperkuat dengan hasil penyebaran kuesioner di SD Gugus VIII Kecamatan Buleleng yang dilaksanakan dari tanggal 6 sampai dengan 11 November 2020 yang diberikan kepada guru kelas IV memperoleh hasil bahwa $75 \%$ guru menyatakan cakupan materi di buku ajar IPS yang tersedia terbatas, $75 \%$ guru merasa kalau tampilan buku materi ajar kurang menarik, 75\% guru menyatakan media pembelajaran yang tersedia di sekolah terbatas, 87,5\% guru menyatakan belum tersedianya media pembelajaran berupa komik digital di sekolah, 37,5\% guru menyatakan materi IPS sangat perlu dan 62,5\% lagi guru menyatakan materi IPS perlu dikembangkan atau dikemas kedalam media komik digital.

Kondisi pembelajaran yang hanya menggunakan buku siswa dengan keterbatasan materi terutama pada muatan IPS mengakibatkan kurangnya pemahaman ilmu sosial dari siswa yang terus menurun (Sukriyatun, 1970). Apabila hal tersebut terus dibiarkan terjadi maka kualitas pendidikan menjadi menurun. Penggunaan media yang kurang optimal dalam pembelajaran juga mengakibatkan guru mengalami kesulitan dalam menjelaskan materi terutama yang bersifat abstrak, dimana hal tersebut mengakibatkan siswa harus berpikir secara abstrak sehingga siswa menjadi minim pengetahuan konsep yang diajarkan dan sulit dalam mengingat materi pembelajaran dalam jangka waktu panjang yang berpengaruh terhadap hasil belajarnya.

Dari keadaan tersebut, perlu adanya transformasi proses pembelajaran kearah yang lebih baik lagi agar suasana pembelajaran menjadi lebih menyenangkan. Pembelajaran dapat dikatakan menyenangkan apabila dalam proses belajar siswa aktif, semangat dan mampu memahami yang dijelaskan dengan baik. Hal tersebut dapat diatasi dengan mengembangkan media bacaan menjadi lebih menarik lagi baik dari segi bahasa penyampaian maupun tampilannya. Oleh karena itu diperlukannya pengembangan media komik digital. Komik digital adalah komik sederhana yang berisi gambar dan suara kemudian dikemas ke dalam media elektronik tertentu (Yuliana et al., 2017). Komik yang telah dikemas ke dalam bentuk digital merupakan salah satu perantara dalam penyampaian informasi pembelajaran untuk memudahkan pemahaman materi yang abstrak menjadi lebih konkret. Penggunaan media dalam pembelajaran bertujuan sebagai sumber belajar dan mampu memotivasi minat siswa untuk meningkatkan hasil belajar (Hidayah \& Ulva, 2017).

Adapun kelebihan pengembangan komik digital ini yaitu pembelajaran menjadi lebih menarik karena siswa dapat belajar melalui unsur audio (suara) dan visual (gambar). Dimana media dengan memiliki unsur audio visual mampu menyampaikan materi pembelajaran menjadi lebih jelas dan mudah dicerna karena siswa menjadi tidak berpikir abstrak (Hilmi, 2017). Mampu menggambarkan kejadian-kejadian dalam waktu yang singkat, informasi yang disampaikan cepat dan mudah, mengembangkan pikiran dan partisipasi siswa, mampu mengembangkan imajinasi siswa. Penyampaian materi memiliki alur cerita yang runtut sehingga mudah untuk dipahami dan diingat oleh siswa (Raneza \& Widowati, 2020). Dengan diterapkannya pengembangan media ini maka proses pembelajaran menjadi lebih bermakna (Nugraha, 2020).

Penelitian pengembangan ini didukung oleh penelitian yang telah dilakukan oleh beberapa peneliti yaitu (1) penelitian Salahuddin et al., (2019) menunjukkan bahwa pengembangan media komik digital dengan unsur visual pada pembelajaran IPS layak untuk digunakan dalam proses pembelajaran, (2) penelitian (Ernawati et al., 2019) menunjukkan bahwa pengembangan komik digital 
ekonomi untuk generasi milenial berisi visualisasi dinyatakan efektif digunakan sebagai media inovatif yang mampu menarik perhatian siswa sehingga memudahkan siswa memahami materi pembelajaran, (3) penelitian Sukmanasa et al., (2017) memperoleh hasil bahwa media komik digital pada mata pelajaran ilmu pengetahuan sosial berdasarkan validasi oleh ahli materi, ahli media, dan tanggapan guru serta siswa layak digunakan untuk meningkatkan minat belajar siswa dalam proses pembelajaran, (4) penelitian Pravitasari et al., (2017) tentang komik digital mengenai pengaruh negatif media sosial pada remaja menunjukkan hasil bahwa media tersebut efektif digunakan sebagai cerminan remaja dalam penggunaan media sosial dan 4) penelitian lainnya yang dilakukan oleh Kanti et al., (2018) berdasarkan dari uji ahli, uji kelompok besar dan uji kelompok kecil yang telah dilaksanakan mendapat hasil bahwa media komik digital menarik, efisien dan efektif digunakan dalam proses pembelajaran pada kompetensi dasar sistem pembayaran dan alat pembayaran untuk siswa. Penelitian yang telah dilaksanakan tersebut berkaitan dengan penelitian yang dilakukan yaitu pada pengembangan media komik digital.

Perbedaan penelitian ini dengan penelitian yang dilaksanakan sebelumnya yaitu pada penelitian ini mengembangkan media komik digital dengan mengandung unsur audio dan visual pada topik sumber daya alam siswa kelas IV SD sedangkan penelitian sejenis sebelumnya belum pernah mengembangkan media komik digital topik sumber daya alam siswa kelas IV SD dengan unsur audio (sumber suara dari dialog tokoh karakter) dan visual (gambar) yang disertai dengan animasi yang mampu bergerak seperti objek nyata pada.

Adapun tujuan dari penelitian ini yakni untuk mengembangkan media komik digital pada topik sumber daya alam siswa kelas IV sekolah dasar yang teruji validitasnya. Adanya media komik digital dapat membantu guru menjelaskan suatu materi yang susah diterjemahkan oleh siswa, mendorong semangat dan minat siswa dalam belajar dengan demikian proses pembelajaran menjadi lebih bermakna sehingga mampu mempengaruhi hasil belajar siswa dan tercapainya tujuan pembelajaran.

\section{Metode}

Penelitian ini merupakan penelitian pengembangan (Research and Development) yang mengadaptasi model pengembangan ADDIE. Pemilihan model ini didasarkan karena memiliki alur tahapan pengembangan yang sistematis, jelas dan terprogram dengan urutan kegiatan yang terurut dalam memecahkan suatu permasalahan belajar yang berhubungan dengan sumber belajar (Tegeh et al., 2015). Model ADDIE terdiri dari beberapa tahapan yaitu (1) analyze (analisis), (2) design (perancangan), (3) development (pengembangan), (4) implementation (implementasi), dan (5) evaluation (evaluasi) (Cahyadi, 2019). Adapun tahap yang tidak dapat dilaksanakan adalah tahap implementasi dan evaluasi karena keterbatasan waktu, situasi dan kondisi. Secara lebih jelas, tahapan pengembangan ini disajikan pada Gambar 01.

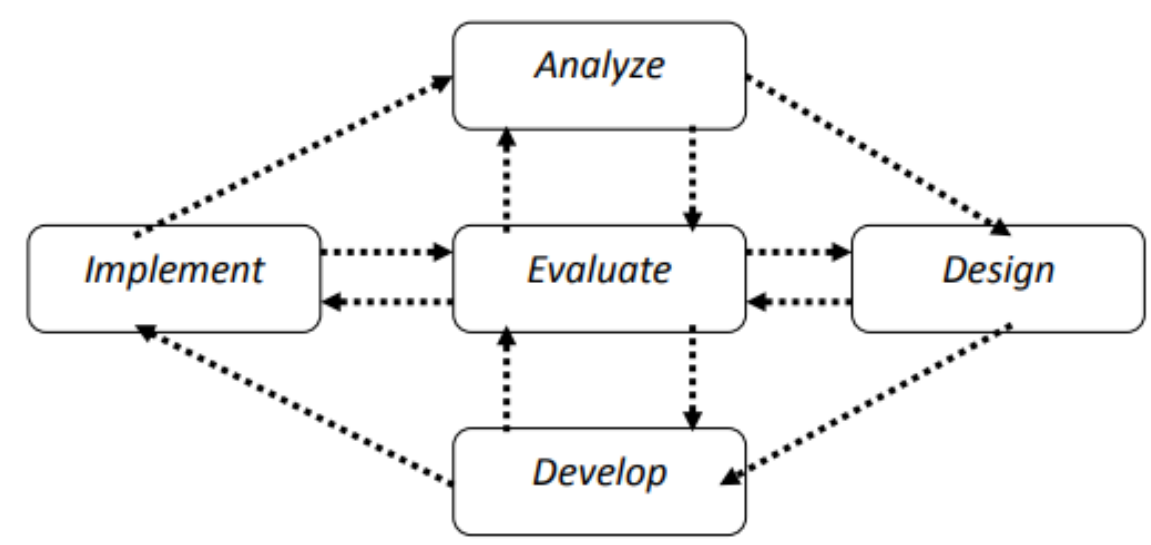

Gambar 01. Tahapan Model ADDIE (Sumber: Tegeh et al., 2015)

Subjek penelitian ini berupa produk media komik digital dengan topik sumber daya alam siswa kelas IV SD dan ahli yang kompeten pada bidangnya. Ahli tersebut terdiri dari dua orang dosen sebagai ahli materi yang kompeten dalam muatan IPS, dua orang dosen sebagai ahli media untuk memberikan review media yang telah dikembangkan, dua orang guru sebagai praktisi dan kelompok kecil sejumlah 
lima orang siswa. Dengan objek penelitian yaitu validitas media komik digital pada topik sumber daya alam siswa kelas IV SD.

Metode dan instrumen pengumpulan data yang digunakan dalam penelitian pengembangan ini adalah rating scale. Rating scale merupakan data mentah yang berbentuk angka kemudian diartikan menjadi suatu kalimat atau kata, contohnya baik-buruk, lemah-kuat dan lain-lain (Ilhami \& Rimantho, 2017). Instrumen rating scale yang dipakai adalah lembar penilaian komik digital. Adapun kisi-kisi dari lembar penilaian komik digital disajikan pada tabel berikut.

Tabel 1. Kisi-kisi Instrumen Validasi Media Ahli Materi

\begin{tabular}{ll}
\hline \multicolumn{1}{c}{ Aspek } & \multicolumn{1}{c}{ Dimensi } \\
\hline Materi/ isi & Kelengkapan dan kejelasan dalam menyampaikan identitas \\
& Penyampaian tujuan pembelajaran jelas \\
& Penyampaian materi dengan jelas \\
Bahasa/ Komunikasi & Kesesuaian penggunaan kaidah bahasa \\
& Menggunakan bahasa yang mudah dipahami siswa \\
Penyajian & Ke runtutan dalam penyajian \\
& Keterpaduan dalam penyajian \\
\hline
\end{tabular}

Tabel 2. Kisi-kisi Instrumen Validasi Ahli Media

\begin{tabular}{cl}
\hline Aspek & \multicolumn{1}{c}{ Dimensi } \\
\hline \multirow{2}{*}{ Suara dan teks } & Teks disajikan dengan jelas \\
& Suara disajikan dengan jelas \\
& Ilustrasi disajikan dengan jelas \\
Visual & Tampilan background menarik \\
& Perpaduan dalam penggunaan warna \\
Penokohan & Pemilihan karakter tokoh \\
Tampilan Keseluruhan & Kemenarikan Karakter Tokoh \\
\hline
\end{tabular}

Tabel 3. Kisi-kisi Instrumen Respon Praktisi dan Siswa

\begin{tabular}{|c|c|}
\hline Aspek & Dimensi \\
\hline \multirow{3}{*}{ Materi/ isi } & Kelengkapan dan kejelasan dalam menyampaikan identitas \\
\hline & Penyampaian tujuan pembelajaran jelas \\
\hline & Penyampaian materi dengan jelas \\
\hline \multirow{2}{*}{ Bahasa/ Komunikasi } & Kesesuaian penggunaan kaidah bahasa \\
\hline & Menggunakan Bahasa yang mudah dipahami siswa \\
\hline \multirow{2}{*}{ Penyajian } & ke runtutan dalam penyajian \\
\hline & Keterpaduan dalam penyajian \\
\hline \multirow{2}{*}{ Suara dan teks } & Teks disajikan dengan jelas \\
\hline & Suara disajikan dengan jelas \\
\hline \multirow{3}{*}{ Visual } & Ilustrasi disajikan dengan jelas \\
\hline & Tampilan background menarik \\
\hline & Perpaduan dalam penggunaan warna \\
\hline \multirow{2}{*}{ Penokohan } & Pemilihan karakter tokoh \\
\hline & Kemenarikan Karakter Tokoh \\
\hline Tampilan Keseluruhan & Keterpaduan tampilan keseluruhan \\
\hline
\end{tabular}

Pembuatan instrumen diawali dengan pembuatan tabel kisi-kisi, berkonsultasi dengan dosen pembimbing dan menyusun instrumen dengan tujuh aspek yaitu aspek materi/isi, Bahasa/komunikasi, penyajian, suara dan teks, visual, penokohan dan tampilan keseluruhan. Instrumen yang telah dibuat kemudian diuji untuk mengetahui validitas isi instrumen yang dilakukan oleh dua ahli (judges) yang ahli di bidangnya. Uji validitas isi instrumen menggunakan rumus Gregory. 
Data yang diperoleh dari ahli (judges) kemudian dikonversikan ke dalam tabulasi silang $2 \times 2$. Uji validitas instrumen yang telah dilaksanakan memperoleh hasil 0.86 untuk instrumen ahli materi, 0.93 untuk instrumen ahli media dan 0.90 untuk instrumen respon praktisi dan 0.93 untuk instrumen respon siswa. Dengan demikian berdasarkan kriteria validitas isi, koefisien validitas isi instrumen penilaian media komik digital berada pada kriteria validitas isi sangat tinggi.

Teknik analisis data dalam penelitian ini adalah analisis deskriptif kualitatif dan kuantitatif. Analisis deskriptif kualitatif digunakan untuk mengolah data yang berupa saran dan masukan dari para ahli dan respon yang diberikan oleh guru maupun siswa guna memperbaiki media yang telah dikembangkan. Analisis deskriptif kuantitatif digunakan untuk mengolah hasil data expert judgement dari para ahli juga hasil data respon praktisi dan respon siswa. Data expert judgment berupa skor yang diperoleh dari pemberian lembar penilaian kepada ahli materi dan ahli media kemudian dihitung guna mengetahui validitas isi komik digital dengan memakai rumus indeks validitas Aiken. Hasil indeks validitas Aiken kemudian dikonversikan ke dalam kriteria validitas Aiken seperti pada Tabel 4.

Tabel 4. Kriteria Indeks Validitas Aiken

\begin{tabular}{ll}
\hline Rentangan Indeks Validitas Aiken & Kriteria \\
\hline $\mathrm{V} \leq 0.4$ & Validitas Rendah \\
$0.4<\mathrm{V}<0.8$ & Validitas Sedang \\
$\mathrm{V} \geq 0.8$ & Validitas Tinggi \\
\hline
\end{tabular}

(Retnawati, 2016)

Hasil data respon praktisi dan siswa berupa skor yang diperoleh dari lembar penilaian yang diberikan kemudian dihitung menggunakan rumus mean. Rata-rata skor yang didapatkan kemudian dikonversikan menggunakan pedoman konversi skala lima guna mengetahui validitas media yang dikembangkan. Pedoman konversi skala lima disajikan pada Tabel 5.

Tabel 5. Pedoman Konversi Skala Lima

\begin{tabular}{cc}
\hline Rentangan Skor & Predikat \\
\hline $4,0<\mathrm{X} \leq 5,0$ & Sangat Baik \\
$3,3<\mathrm{X} \leq 4,0$ & Baik \\
$2,7<\mathrm{X} \leq 3,3$ & Cukup \\
$2,00<\mathrm{X} \leq 2,7$ & Tidak Baik \\
$1,0<\mathrm{X} \leq 2,0$ & Sangat Tidak Baik \\
\hline
\end{tabular}

(Koyan, 2012).

\section{Hasil dan Pembahasan}

Produk yang dihasilkan dalam pengembangan ini berupa media komik digital pada topik sumber daya alam yang dikembangkan dengan menggunakan model ADDIE. Media komik digital ini dirancang untuk siswa kelas IV sekolah dasar, yaitu pada tema 9 kayanya negeriku. Media tersebut dikembangkan melalui tiga tahap yaitu analyze, design, dan development.

Pada tahap pertama yaitu analyze (analisis) meliputi beberapa kegiatan yaitu (1) analisis kebutuhan sumber belajar yang dibutuhkan oleh guru dan siswa seperti keefektifan pembelajaran tema 9 dengan buku ajar dan pengalaman penggunaan media komik digital topik sumber daya alam kelas IV SD; (2) analisis kurikulum seperti silabus, kompetensi dasar, indikator, buku guru dan siswa; (3) analisis karakteristik siswa meliputi kognitif siswa berada pada tahap operasional konkret; (4) analisis karakteristik media pembelajaran komik digital untuk siswa. Kedua, tahap design (perancangan) menghasilkan storyline dan rancang bangun media komik digital topik sumber daya alam siswa kelas IV SD sesuai dengan KD dan indikator pencapaian pembelajaran yang telah dianalisis. Ketiga, tahap development (pengembangan) mampu menghasilkan atau mengembangkan produk pembelajaran berupa media komik digital yang telah teruji validitasnya melalui proses penilaian dari tim ahli, respon guru dan siswa. 
Hasil penialaian dari dua orang dosen ahli materi, dua orang dosen ahli media, serta penilaian dari respom dua orang guru sebagai praktisi dan lima orang siswa menyatakan bahwa media komik digital pada topik sumber daya alam siswa kelas IV SD secara menyeluruh berada pada kategori atau predikat sangat baik dan layak. Terlihat dari penilaian dua orang ahli materi dan ahli media secara berturut-turut mememperoleh hasil indeks validitas aiken terendah $0.88,0.63$ dan tertinggi sebesar 1 dengan interpretasi menggunakan kriteria kurang dari 0.4 maka validitasnya rendah, diantara 0.4-0.8 validitasnya sedang (mediocare) dan lebih dari 0,8 maka validitasnya tinggi. Hasil dari respon praktisi memperoleh rata-rata skor sebesar 4.62 dan respon siswa dengan rata-rata skor sebesar 4.87. Jika dikonversikan dalam pedoman konversi skala lima berada pada rentang skor $4.01<\mathrm{X} \leq 5.01$ dengan predikat sangat baik. Secara lebih jelas hasil validitas media komik digital disajikan pada Tabel 6 dan tabel 7.

Tabel 6. Hasil Penilaian Indeks Validitas Aiken Ahli Materi dan Ahli Media

\begin{tabular}{cccc}
\hline Indeks & Ahli Materi & Ahli Media & Kategori \\
\hline Terendah & 0.88 & 0.63 & Valid \\
Tertinggi & 1 & 1 & Sangat Valid \\
\hline
\end{tabular}

Tabel 7. Hasil Rata-rata Skor Respon Praktisi dan Respon Siswa

\begin{tabular}{lccc}
\hline \multicolumn{1}{c}{ Aspek } & $\begin{array}{c}\text { Respon } \\
\text { Praktisi }\end{array}$ & Respon Siswa & Predikat \\
\hline Materi/Isi & 4.63 & 4.90 & Sangat Baik \\
Kebahasaan/Komunikasi & 4.63 & 5.00 & Sangat Baik \\
Penyajian & 4.83 & 4.90 & Sangat Baik \\
Suara dan teks & 4.75 & 4.95 & Sangat Baik \\
Visual & 4.5 & 4.93 & Sangat Baik \\
Penokohan & 4.33 & 5.00 & Sangat Baik \\
Penampilan keseluruhan & 4.75 & 5.00 & Sangat Baik \\
\hline
\end{tabular}

Hasil data berupa masukan, saran dan komentar yang diberikan setelah memberikan lembar penilaian digunakan sebagai bahan pertimbangan guna memperbaiki media yang telah dikembangkan. Adapun beberapa tampilan bagian media komik digital pada topik sumber daya alam siswa kelas IV SD dapat dilihat pada Gambar 2.

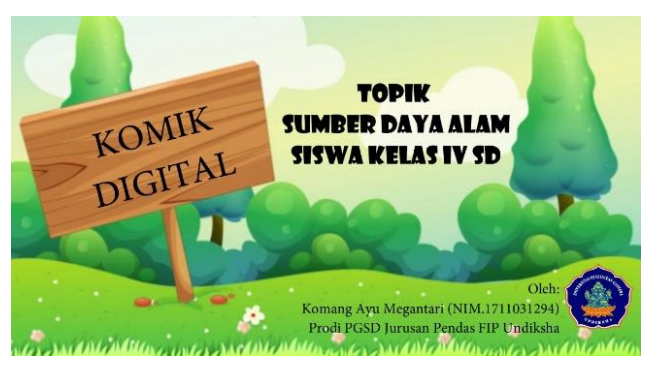

(a) Sampul Komik Digital

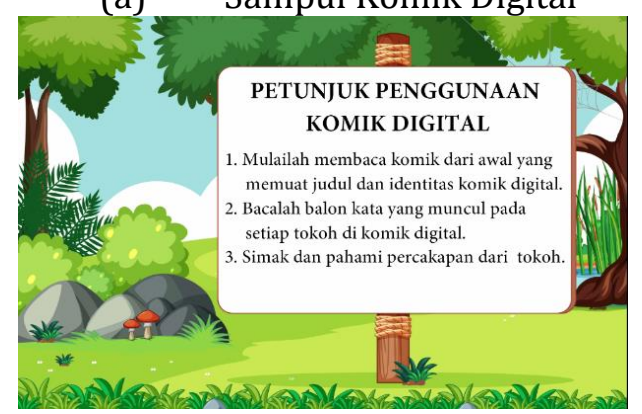

(c) Petunjuk Penggunaan

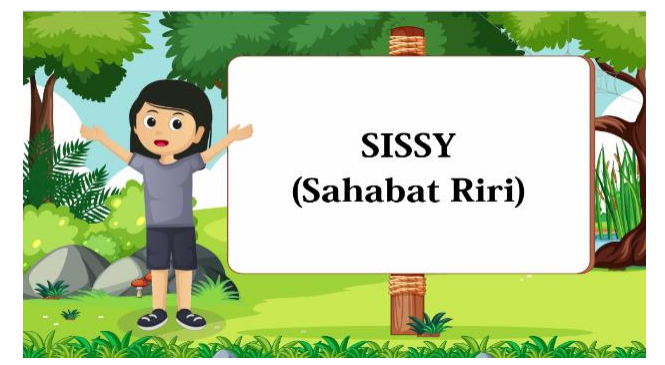

(b) Perkenalan Tokoh

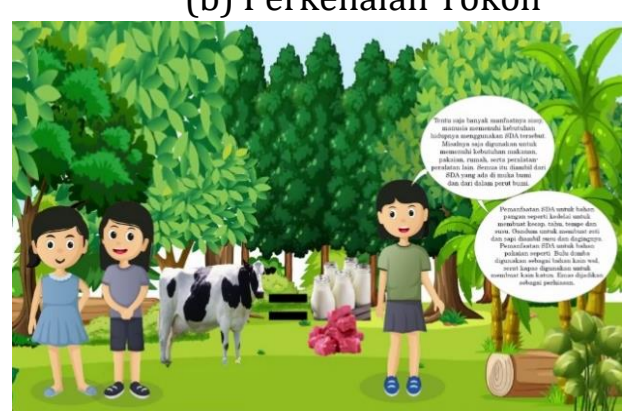

(d) Bagian Isi

Gambar 2. Bagian Sampul, Perkenalan Tokoh, Petunjuk Penggunaan dan Bagian Isi 


\section{Pembahasan}

Tahap analisis (analyze), pada tahap ini dilaksanakan kegiatan analisis kebutuhan, analisis kurikulum, analisis karakteristik siswa dan analisis media. Pada analisis kebutuhan memperoleh hasil bahwa bahwa guru dan siswa membutuhkan media pembelajaran yang inovatif dan kreatif. Dengan adanya media tersebut mampu untuk mendorong proses pembelajaran menjadi lebih ideal, bermakna serta menyenangkan (Andrian, 2017). Berdasarkan hasil analisis kurikulum dinyatakan bahwa dengan menggunakan kurikulum 2013 proses pembelajaran dituntut agar mampu menciptakan suasana belajar dengan sumber belajar dan metode yang menyenangkan (Mardiana \& Sumiyatun, 2017). Hasil analisis karakteristik siswa kelas IV SD berada pada tahap operasional konkret yang sudah mampu berpikir logis terhadap sesuatu yang bersifat nyata jika dibantu oleh benda-benda konkret (Juwantara, 2019). Untuk hasil analisis media memperoleh hasil bahwa di sekolah belum pernah mengembangkan materi ke dalam media komik digital, sehingga dalam proses belajar mengajar terutama pada muatan IPS hanya menggunakan peta, globe dan buku siswa yang materi di dalamnya masih terbatas dengan gambar-gambar dan contoh-contoh yang masih bersifat abstrak.

Tahap perancangan (design), pada tahap ini dilaksanakan perancangan media komik digital dengan menentukan topik yang dipilih yaitu sumber daya alam siswa kelas IV SD tema 9 kayanya negeriku. Dilanjutkan dengan pembuatan storyline yang berguna sebagai panduan untuk mempermudah pembuatan media, kemudian diperlihatkan ke dosen pembimbing terlebih dahulu guna mendapatkan saran dan masukan untuk memperbaiki rancangan yang telah dibuat kemudian dilanjutkan ke tahap pengembangan media komik digital sesuai dengan rancangan yang telah dibuat.

Tahap pengembangan (development), merupakan tahap terakhir dalam pengembangan media komik digital. Pada tahap ini dilakukan pengembangan media komik digital topik sumber daya alam yang terdiri dari komponen-komponen karakter tokoh, background, dubbing suara, dan dioalog penyampaian materi yang kemudian dijadikan satu kesatuan dalam bentuk video dengan rasio 16:9 menggunakan aplikasi filmora. Setelah produk selesai dikembangkan maka dilaksanakan uji validitas oleh ahli materi, ahli media, praktisi dan siswa kelas IV SD dengan memberikan lembar penilaian yang memuat aspek materi, kebahasaan, suara dan teks, penyajian, penokohan, visual dan tampilan keseluruhan. Berdasarkan penelitian yang telah dilaksanakan oleh dua orang dosen ahli materi dan dua orang dosen ahli media media komik digital yang dikembangkan telah valid secara isi. Hasil dari dua orang respon praktisi dan respon lima orang siswa terhadap media komik digital mendapatkan respon yang sangat baik, sehingga media komik digital pada topik sumber daya alam layak digunakan sebagai sumber belajar yang akan digunakan dalam proses pembelajaran.

Hasil penelitian oleh dua orang ahli materi memperoleh hasil indeks terendah 0.88 dengan validitas isi sedang dan indeks validitas tertinggi 1 dengan validitas isi sangat tinggi. Hasil tersebut menunjukkan bahwa materi yang terdapat dalam media valid sebagai media pembelajaran. Hal tersebut disebabkan karena (1) dalam media komik digital materi dan tujuan pembelajaran disampaikan dengan jelas serta sudah sesuai dengan kompetensi dasar dan indikator, (2) dalam penyampaian materi menggunakan bahasa dan kalimat yang mudah dipahami oleh siswa. Kesesuaian materi dan tujuan pembelajaran dengan kompetensi dasar serta indikator dapat meningkatkan kemampuan dan keberhasilan siswa serta guru untuk mencapai tujuan pembelajaran dengan efektif (Sunarto et al., 2019). Selain itu, penggunaan bahasa yang mudah dipahami mampu membuat siswa dengan mudah untuk memahami materi pembelajaran dengan baik (Munthe \& Naibaho, 2019).

Hasil penelitian dari dua orang dosen ahli media memperoleh indeks validitas terendah 0.63 dan indeks tertinggi sebesar 1 dengan kategori validitas isi sangat tinggi. Hasil tersebut dipengaruhi oleh beberapa aspek yaitu (1) aspek suara, dimana suara disajikan dengan jelas disertai dengan musik sebagai backsound, (2) aspek visual, menggunakan warna yang sesuai dan harmonis dengan tampilan gambar dan background. Dengan aspek suara dan visual yang sesuai dan harmonis proses pembelajaran menjadi lebih menarik serta dapat membantu guru untuk menjelaskan materi pembelajaran yang abstrak sehingga siswa mudah untuk memahami materi (Mawardi et al., 2019). Hal lain juga disampaikan oleh Paramita et al., (2019) bahwa dengan pemberian warna yang sesuai dengan keadaan aslinya mampu menarik perhatian siswa untuk belajar.

Setelah melakukan review dari tim ahli, dilanjutkan dengan mencari respon praktisi dan respon siswa dengan perolehan rata-rata skor sebesar 4.62 dari praktisi dan respon siswa sebesar 4.95 dengan predikat sangat baik. Hal tersebut dikarenakan media komik digital yang dikembangkan mampu mendorong semangat dan minat siswa untuk melaksanakan pembelajaran. Penggunaan media 
yang sesuai dengan karakteristik siswa dalam pembelajaran dapat membantu siswa dalam memahami suatu materi yang bersifat abstrak dan mampu meningkatkan hasil maupun prestasi belajar siswa (Ekayani, 2017).

Hal tersebut sejalan dengan teori Piaget yang menyatakan bahwa anak sekolah dasar berada pada tahap operasional konkret (Bujuri, 2018) yang berarti bahwa anak dapat mengerti jika dibantu dengan bantuan benda konkret (Ningrum, 2021). Benda konkret yang dapat dimanfaatkan untuk membantu pemahaman siswa adalah dengan menggunakan media komik digital yang telah dikembangkan. Media komik digital merupakan alam bantu untuk menyampaikan materi pembelajaran dalam bentuk teks cerita bergambar yang disampaikan oleh karakter tokoh dalam komik yang dikemas secara digital. Komik digital memiliki aspek materi/isi, aspek kebahasaan atau komunikasi (Siti Nurjanah \& Sumarmi, 2020), aspek penyajian, aspek suara dan teks, aspek visual (Yuliana et al., 2017), aspek penokohan dan aspek penampilan keseluruhan (Bujuri, 2018) yang mampu membuat media menjadi lebih menarik. Berdasarkan dari aspek tersebut media komik digital memiliki unsur audio (suara) dan visual (gambar).

Kelayakan media komik digital juga dapat dilihat dari keunggulan yang dimiliki pada media ini yang menampilkan unsur suara dan unsur gambar sekaligus dalam sekali penayangan secara digital yang mampu meningkatkan minat dan semangat siswa untuk belajar (Pradilasari et al., 2019). Penyampaian materi pembelajaran bervariasi sehingga tidak membosankan dan memberikan pengalaman belajar yang sulit dipelajari secara langsung (Suprianto, 2019), memperkuat pemahaman dan ingatan siswa terhadap materi pembelajaran (Alwi, 2017) dan dengan unsur audio yaitu sumber suara karakter tokoh juga musik yang ada di dalamnya dan unsur visual yaitu gambar-gambar dengan warna-warna beragam yang ada dalam media komik digital sangat memudahkan bagi siswa untuk memahami materi dan dapat berimajinasi atau membayangkan tampilan dari materi yang diberikan oleh guru dalam proses pembelajaran (Ariyana et al., 2020)

Sejalan dengan penelitian yang dilakukan oleh (Nurdianto, 2010) yang menjelaskan bahwa media komik digital pada materi menceritakan kembali isi teks biografi pada tim ahli (materi dan media), guru, serta siswa secara berurutan menunjukkan presentase tingkat kevalidan atau kelayakan produk mencapai $81.25 \%, 85.52 \%, 83.75 \%$, dan $82.88 \%$ secara tertulis telah valid dan layak digunakan di lapangan. Penelitian lain yang sesuai yaitu pada penelitian yang dilaksanakan oleh (Hakim, 2018) yang menyatakan bahwa pengembangan media komik digital sebagai media pembelajaran alat-alat pembayaran layak digunakan dilihat dari hasil penilaian dari para ahli diperoleh rerata keseluruhan sebesar 4.42 dan uji validitas sebesar 5.69 yang masuk kategori layak. Berdasarkan hasil dari penelitian yang telah dilakasanakan media komik digital yang dikembangkan ini berbeda dengan penelitian sejenis sebelumnya karena belum pernah ada yang mengembangkan media komik digital pada topik sumber daya alam siswa kelas IV SD yang berada pada tema 9 kayanya negeriku. Disamping itu, media komik digital yang dikembangkan memiliki unsur audio dan visual yang dapat bergerak seperti nyata yang mampu membuat proses pembelajaran menjadi lebih menyenangkan. Media komik digital ini dikembangkan berpedoman dari hasil analisis kebutuhan, analisis kurikulum, analisis media dan karakteristik siswa sehingga media komik digital ini dapat dijadikan alternatif dari permasalahan-permasalahan yang muncul dalam proses pembelajaran.

Berdasarkan dari keadaan tersebut maka media komik digital pada topik sumber daya alam yang terdapat pada buku siswa kelas IV SD tema 9 kayanya negeriku dapat dijadikan sebagai media pembelajaran yang sangat baik dan layak untuk digunakan dalam proses pembelajaran sehingga memudahkan guru untuk menyampaikan suatu materi pembelajaran dan mempermudah siswa untuk memahami suatu materi pembelajaran yang bersifat abstrak.

\section{Simpulan}

Dari hasil penelitian yang telah dilakukan media yang dikembangkan valid, dilihat dari aspek materi atau isi mata pelajaran, visualisasi dan aspek suara yang berada pada predikat sangat baik berdasarkan uji validitas yang telah dilaksanakan oleh ahli materi, ahli media, respon praktisi dan respon siswa. Dengan demikian media komik digital yang telah dikembangkan dapat digunakan sebagai media pembelajaran inovatif oleh guru dan siswa dalam proses pembelajaran yang lebih menyenangkan dan bermakna. 


\section{Daftar Pustaka}

Abdullah, R. (2017). Pembelajaran Dalam Perspektif Kreativitas Guru Dalam Pemanfaatan Media Pembelajaran. Lantanida Journal, 4(1), 35. https://doi.org/10.22373/lj.v4i1.1866

Alwi, S. (2017). Problematika Guru Dalam Pengembangan Media Pembelajaran. Itqan, 8(2), 145-167. http://ejurnal.iainlhokseumawe.ac.id/index.php/itqan/article/download/107/65/

Andrian, R. (2017). Pembelajaran Bermakna Berbasis Post It. Jurnal Mudarrisuna, 7(1), 103-118. https://doi.org/http://dx.doi.org/10.22373/jm.v7i1.1911

Anugraheni, I. (2017). Analisa Faktor-Faktor yang Mempengaruhi Proses Belajar Guru-Guru Sekolah $\begin{array}{llll}\text { Dasar. Kelola: Jurnal Manajemen } 205 . & \end{array}$ https://doi.org/10.24246/j.jk.2017.v4.i2.p205-212

Ariyana, Ramdhani, I. S., \& Sumiyani. (2020). Merdeka Belajar Melalui Penggunaan Media Audio Visual Pada Pembelajaran Menulis Teks Deskripsi. 3, 356-370. https://doi.org/https://doi.org/10.31540/silamparibisa.v3i2.1112

Bujuri, D. A. (2018). Analisis Perkembangan Kognitif Anak Usia Dasar dan Implikasinya dalam Kegiatan Belajar Mengajar. LITERASI (Jurnal Ilmu Pendidikan), 9(1), 37. https://doi.org/10.21927/literasi.2018.9(1).37-50

Cahyadi, R. A. H. (2019). Pengembangan Bahan Ajar Berbasis Addie Model. Halaqa: Islamic Education Journal, 3(1), 35. https://doi.org/10.21070/halaqa.v3i1.2124

Dwijayani, N. M. (2019). Development of circle learning media to improve student learning outcomes. Journal of Physics: Conference Series, 1321(2), 171-187. https://doi.org/10.1088/17426596/1321/2/022099

Ekayani, P. (2017). (2017). Pentingnya Penggunaan Media Pembelajaran Untuk Meningkatkan Prestasi Belajar Siswa. March. https://www.researchgate.net/publication/315105651

Ernawati, Y., Rufii, \& Waluyo, D. A. (2019). Komik Digital Ekonomi Untuk Generasi Milenial. 7(4), 117120.

Firmadani, F. (2020). Media Pembelajaran Berbasis Teknologi Sebagai Inovasi Pembelajaran Era Revolusi Industri 4.0. Prosiding Konferensi Pendidikan Nasional, ISSN: 2654-8607, 93-97. https://ejurnal.mercubuana-yogya.ac.id

Hakim, A. F. (2018). Pengembangan Komik Digital Sebagai Media Pembelajaran Alat-Alat Pembayaran Internasional. Jurnal Pendidikan Dan Ekonomi, 7(3), 204-212.

Hidayah, N., \& Ulva, R. K. (2017). Pengembangan media pembelajaran berbasis komik pada mata pelajaran ilmu pengetahuan sosial kelas IV MI Nurul Hidayah Roworejo Negerikaton Pesawaran. Jurnal Pendidikan Dan Pembelajaran Dasar, 4(1), 34-46. http://ejournal.radenintan.ac.id

Hilmi, H. (2017). Efektivitas Penggunaan Media Gambar Dalam Pembelajaran Bahasa Arab. Lantanida Journal, 4(2), 128. https://doi.org/10.22373/lj.v4i2.1885

Ilhami, R. S., \& Rimantho, D. (2017). Penilaian Kinerja Karyawan dengan Metode AHP dan Rating Scale. Jurnal Optimasi Sistem Industri, 16(2), 150. https://doi.org/10.25077/josi.v16.n2.p150157.2017

Juwantara, R. A. (2019). Analisis Teori Perkembangan Kognitif Piaget pada Tahap Anak Usia Operasional Konkret 7-12 Tahun dalam Pembelajaran Matematika. Al-Adzka: Jurnal Ilmiah $\begin{array}{llll}\text { Pendidikan Guru Madrasah } & \text { Ibtidaiyah, }\end{array}$ https://doi.org/10.18592/aladzkapgmi.v9i1.3011

Kanti, F. Y., Suyadi, B., \& Hartanto, W. (2018). Pengembangan Media Pembelajaran Komik Digital Pada Kompetensi Dasar Sistem Pembayaran Dan Alat Pembayaran Untuk Siswa Kelas X Ips Di Man 1 Jember. Jurnal Pendidikan Ekonomi: Jurnal Ilmiah Ilmu Pendidikan, Ilmu Ekonomi Dan Ilmu Sosial, 12(1), 135. https://doi.org/10.19184/jpe.v12i1.7642 
Kharisma, G. I. (2020). Pengaruh Media Pembelajaran Berbasis Android terhadap Kemampuan Memahami Teks Prosedur Siswa Kelas VII. BELAJAR BAHASA: Jurnal Ilmiah Program Studi Pendidikan Bahasa Dan Sastra Indonesia, 5(2), 269-278. https://doi.org/10.32528/bb.v5i2.2795

Larasati, D. A., Wijaya, U., \& Surabaya, K. (2020). Pengaruh Media Peta Berbasis Konstruktivistik Terhadap Hasil Belajar IPS Siswa Sekolah dasar. Jurnal Unma, 3(1), 53-63. http://jurnal.unma.ac.id

Lestari, I. D., Halimatusha'diah, H., \& Puji Lestari, F. A. (2018). Penggunaan Media Audio, Visual, Audiovisual, dalam Meningkatkan Pembelajaran kepada Guru-guru. Jurnal PkM Pengabdian Kepada Masyarakat, 1(01), 55. https://doi.org/10.30998/jurnalpkm.v1i01.2361

Mardiana, S., \& Sumiyatun, S. (2017). Implementasi Kurikulum 2013 Dalam Pembelajaran Sejarah Di Sma Negeri 1 Metro. Historia, 5(1), 45. https://doi.org/10.24127/hj.v5i1.732

Mawardi, G., Iriani, T., \& Daryati, D. (2019). Pengembangan Media Pembelajaran Berbasis Multimedia Pada Mata Kuliah Kompetensi Pembelajaran Pokok Materi Keterampilan Dasar Mengajar. Jurnal Pensil, 8(1), 24-30. https://doi.org/10.21009/jpensil.v8i1.8485

Muammar, M., \& Suhartina, S. (2018). Media Pembelajaran Berbasis Teknologi Informasi dalam Meningkatkan Minat Belajar Akidah Akhlak. KURIOSITAS: Media Komunikasi Sosial Dan Keagamaan, 11(2), 176-188. https://doi.org/10.35905/kur.v11i2.728

Munthe, A. P., \& Naibaho, H. P. (2019). Manfaat dan Kendala Penerapan Tutor Sebaya untuk Siswa Kelas IV Sekolah Dasar Lentera Harapan Mamit. Scholaria: Jurnal Pendidikan Dan Kebudayaan, 9(2), 138-147. https://doi.org/10.24246/j.js.2019.v9.i2.p138-147

Ningrum, G. A. O. (2021). Optimalisasi Keaktifan dan Kemampuan Berhitung dengan Media Benda Konkret pada Siswa Kelas I SDN Kaliwareng. 3(1), 80-89. http://pub.mykreatif.com

Nugraha, D. A. (2020). Pengembangan Komik Kimia Sebagai Media Pembelajaran Berbasis Cet (ChemoEdutainment). Chemistry in Education, 9(2), 84-90. https://journal.unnes.ac.id

Nurdianto, I. (2010). Pengembangan Media Pembelajaran Komik Digital Berbasis Platform Google Classroom Pada Materi Menceritakan Kembali Isi Teks Biografi. Journal of Chemical Information and Modeling, 8. http://www.riset.unisma.ac.id

Paramita, R., Panjaitan, R. G. P., \& Ariyati, E. (2019). Pengembangan Booklet Hasil Inventarisasi Tumbuhan Obat Sebagai Media Pembelajaran Pada Materi Manfaat Keanekaragaman Hayati. Jurnal IPA \& Pembelajaran IPA, 2(2), 83-88. https://doi.org/10.24815/jipi.v2i2.12389

Pradiatiningtyas, D., \& Suparwanto. (2017). E-Learning Sebagai Media Pembelajaran Berbasis Web Pada Smk N 4 Purworejo. 7(2), 1-8. https://doi.org/http://dx.doi.org/10.2311/ijns.v7i2.1499

Pradilasari, L., Gani, A., \& Khaldun, I. (2019). Pengembangan Media Pembelajaran Berbasis Audio Visual pada Materi Koloid Untuk Meningkatkan Motivasi dan Hasil Belajar Siswa SMA. 07(01), 9-15. https://doi.org/10.24815/jpsi.v7i1.13293

Pravitasari, T. A., Adib, A., \& Wahyudi, A. T. (2017). Perancangan Komik Digital Mengenai Pengaruh Negatif Media Sosial Pada Remaja Wanita di Surabaya. Jurnal DKV Adiwarna, 1, 2. http://publication.petra.ac.id/index.php/dkv/article/viewFile/5517/5044

Raneza, F., \& Widowati, H. (2020). Analisis Urgensi Pengembangan Komik Digital Dengan Mengintegrasikan Nilai-Nilai Keislaman. Biolova, 1(1), 13-18. https://doi.org/10.24127/biolova.v1i1.28

Salahuddin, Syahnaz, E., Wijaya, V., \& Wahyuni, S. (2019). Pengembangan Media Komik Digital Pada Pembelajaran IPS Siswa SDN 02 Kelas III Kab.Sambas. Journal of Scientech Research and Development, 1(1), 1-11. https://sinta.ristekbrin.go.id

Setiawati, T., Pranata, O. H., \& Halimah, M. (2019). Pengembangan Media Permainan Papan pada Pembelajaran IPS untuk Siswa Kelas V Sekolah Dasar. Pengembangan Media Permainan Papan Pada Pembelajaran IPS Untuk Siswa Kelas V Sekolah Dasar, 6(1), 163-174. 
https://ejournal.upi.edu

Sinsuw, A. A. E., \& Sambul, A. M. (2017). Pelatihan Pengembangan Media Pembelajaran Berbasis Teknologi Informasi Bagi Guru-guru SMP. Jurnal Teknik Elektro Dan Komputer, 6(3), 105-110. https://doi.org/10.35793/jtek.6.3.2017.18070

Siti Nurjanah, \& Sumarmi. (2020). Pengembangan Media Pembelajaran Teka-Teki Silang (Tts) Pada Pembelajaran Tematik Tema Cita-Citaku Kelas Iv Di Mi Al Busyro. PREMIERE: Journal of Islamic Elementary Education, 2(1), 31-42. https://doi.org/10.51675/jp.v2i1.85

Sukmanasa, E., Windiyani, T., \& Novita, L. (2017). Pengembangan Media Pembelajaran Komik Digital Pada Mata Pelajaran Ilmu Pengetahuan Sosial Bagi Siswa Kelas V Sekolah Dasar Di Kota Bogor. Jurnal Pendidikan Sekolah Dasar, 3(2), 171. https://doi.org/10.30870/jpsd.v3i2.2138

Sukriyatun, G. (1970). Penggunaan Model Jigsaw dalam Meningkatkan Pemahaman Siswa Kelas 9.3 pada Pelajaran IPS Materi Sejarah di SMPN 16 Bogor. European Journal of Biochemistry, 13(3), 592-592. https://doi.org/10.1111/j.1432-1033.1970.tb00966.x_1

Sunarto, Setyadi, D., \& Wuryantoro, A. (2019). Peningkatan Kemampuan Guru Menyusun Rencana Pelaksanaan Pembelajaran Melalui Workshop Dalam KKG Mini di SD Negeri 2 Kedungbanteng Ponorogo. Prosiding Seminar Nasional Literasi, 1. https://prosiding.unipma.ac.id

Suprianto, E. (2019). Implementasi Media Audio Visual Untuk Meningkatkan Kemampuan Menulis Teks Eksplanasi. Trapsila: Jurnal Pendidikan Dasar, 1(2Desember), 22-32. https://journal.uwks.ac.id/index.php/trapsila/article/view/810

Tegeh, I. M., Jampel, I. N., \& Pudjawan, K. (2015). Pengembangan Buku Ajar Model Penelitian Pengembangan dengan Model ADDIE. Seminar Nasional Riset Inovatif IV, 208-216. https://eproceeding.undiksha.ac.id/index.php/senari/article/view/507

Yuliana, Siswandari, \& Sudiyanto. (2017). Pengembangan Media Komik Digital Akuntansi Pada Materi Menyusun Laporan Rekonsiliasi Bank Untuk Siswa Smk. Jurnal Pendidikan Dan Kebudayaan, 2(2), 135-146. https://jurnaldikbud.kemdikbud.go.id 